2

I N S A N

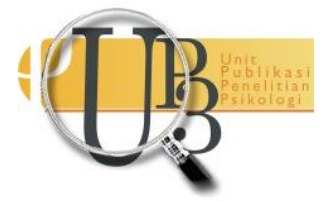

ARTIKEL PENELITIAN

\title{
Hubungan Persepsi Dampak Work Fatigue dengan Persepsi Kualitas Pelayanan Internal Awak Kabin Maskapai Berbiaya Rendah di Indonesia
}

FIKRI AHMAD MAULANA \& CHOLICHUL HADI*

Departemen Psikologi Industri dan Organisasi, Fakultas Psikologi Universitas Airlangga

\begin{abstract}
ABSTRAK
Penelitian ini bertujuan untuk melihat hubungan antara persepsi dampak workfatigue dengan persepsi kualitas pelayanan internal awak kabin maskapai berbiaya rendah di Indonesia. Sebanyak 40 orang awak kabin maskapai berbiaya rendah di Indonesia mejadi subjek dalam penelitian ini. Penelitian ini menggunakan pendekatan kuantitatif dengan tipe penelitian survei. Data diperoleh dengan menggunakan alat ukur Fatigue Impact Scale (FIS) yang terdiri dari 40 item dan alat ukur Pelayanan Penerbangan yang terdiri dari item awal berjumlah 19 item yang kemudian dikurangi menjadi 17 item saja dikarenakan tidak relevan dengan penelitian ini. Hasil dari penelitian ini menunjukkan bahwa persepsi dampak work fatigue tidak memiliki hubungan yang signifikan dengan persepsi kualitas pelayanan internal awak kabin maskapai berbiaya rendah di Indonesia $(p=0,295)$. Sehingga dapat disimpulkan bahwa tidak terdapat hubungan antara persepsi dampak work fatigue dengan persepsi kualitas pelayanan internal pada awak kabin maskapai berbiaya rendah di Indonesia.
\end{abstract}

Kata kunci: awak kabin, kualitas pelayanan, maskapai berbiaya rendah, persepsi, work fatigue

\section{ABSTRACT}

The aim of this research is to determine the relationship between perceived impact of work fatigue and perceived internal service quality among Indonesian Low-Cost Carrier Flight Attendant. The participants of this research were working as flight attendant in Indonesian Low-Cost Airlines, consists of 40 participants. This research uses quantitative approach with survey as the research method. The data are obtained by using Fatigue Impact Scale consisting of 40 items to measure work fatigue, and Airline Hospitality scale consisting of 19 items originally but 2 of the items then had to be eliminated because it is not relevant. The data are then analyzed with Spearman's rho correlation. Based on the analysis result, perceived impact of work fatigue is found to not having any significant relationship with perceived internal service quality. $(p=0,295)$ With that result, the researcher concluded that there is no relationship between perceived impact of work fatigue with perceived intenal service quality among Indonesian Low-Cost Carrier Flight Attendant

Keywords: flight attendant, low-cost carrier airlines, perception, service quality, work fatigue. 
INSAN Jurnal Psikologi dan Kesehatan Mental, 2018, Vol. 3(2), 92-100, doi: 10.20473/jpkm.v3i22018.92-100 Dikirimkan: 16 Oktober 2019 Diterima: 10 Desember 2019 Diterbitkan: 26 Februari 2020

Editor: Rosatyani Puspita Adiati

*Alamat korespondensi: Fakultas Psikologi Universitas Airlangga, Jalan Airlangga 4-6 Surabaya 60286. Pos-el: cholichul.hadi@psikologi.unair.ac.id

Naskah ini merupakan naskah dengan akses terbuka dibawah ketentuan the Creative Common Attribution License (http://creativecommons.org/licenses/by/4.0), sehingga penggunaan, distribusi, reproduksi dalam media apapun atas artikel ini tidak dibatasi, selama sumber aslinya disitir dengan baik.

\section{PENDAHULUAN}

Indonesia sebagai negara kepulauan terbesar di dunia sangat bergantung pada transportasi udara sebagai cara tercepat dalam menghubungkan masyarakatnya satu sama lain. Dewasa ini, transportasi udara tidak lagi dianggap sesuatu yang eksklusif bagi masyarakat. Seiring perkembangan waktu, perjalanan udara sudah menjadi moda transportasi yang banyak digunakan masyarakat, khususnya di Indonesia. Hal ini terlihat dari jumlah penumpang pengguna jasa angkutan udara di Indonesia yang mengalami peningkatan dari tahun ke tahun. Menurut data yang dikeluarkan oleh Badan Pusat Statistik, jumlah penumpang angkutan udara mengalami peningkatan. Peningkatan yang terjadi mencapai 7,27 juta jiwa pada bulan Januari 2017. Jumlah ini meningkat sebesar 15.04 persen bila dibandingkan dengan Januari 2016 yang hanya sebesar 6,32 juta jiwa. Peningkatan ini berlaku juga pada penerbangan tujuan luar negeri sebesar 9,29 persen jika dibandingkan dengan tahun sebelumnya ("Jumlah Penumpang Angkutan Udara", 2017). Meningkatnya tingkat penumpang jasa angkutan udara di Indonesia tidak lepas dari peran maskapai yang menganut sistem Low-Cost. Dalam tiga tahun terakhir, 2015 hingga 2017, Kementerian Perhubungan Indonesia mengatakan, salah satu maskapai di Indonesia yang menganut sistem Low-Cost, Lion Air, menjadi maskapai yang mengangkut penumpang domestik terbanyak di Indonesia.

Lion Air mampu mengangkut penumpang sebanyak 26,48 juta orang pada 2015, atau 35\% dari total jumlah penumpang domestik sebesar 76,62 juta penumpang. Jumlah tersebut mampu mengalahkan maskapai plat merah Garuda Indonesia yang hanya dapat mengangkut 19,96 juta penumpang, atau sekitar 26\% dari total diatas. Di posisi kedua, disusul oleh maskapai yang turut menganut sistem LowCost yaitu Indonesia AirAsia dengan jumlah penumpang yang diangkut sebanyak 3,66 juta orang atau sekitar 15\% dari total jumlah penumpang domestik. ("Lion Air Kuasai", 2016). Sementara di tahuntahun berikutnya, pasar penerbangan di Indonesia masih dikuasai oleh maskapai berbiaya rendah dimana Lion Air dan Citilink Indonesia berada pada peringkat ke-1 dan ke-3 dalam jumlah penumpang ("Produksi Meningkat, Penerbangan Nasional", 2018). Berdasarkan data tersebut, dapat dikatakan bahwa masyarakat Indonesia lebih memilih maskapai Low-Cost untuk melakukan perjalanan udara.

Tingginya permintaan akan kebutuhan maskapai berbiaya rendah di Indonesia dari tahun ke tahun yang tergambar dalam bentuk peningkatan jumlah penumpang dapat disebabkan berbagai kemudahan yang ditawarkan oleh maskapai-maskapai yang menggunakan sistem Low-cost sehingga dapat menjangkau berbagai lapisan konsumen, serta menawarkan keuntungan yang dapat dinikmati pengguna jasa penerbangan. Beberapa keuntungan yang dapat dinikmati dari sisi penumpang seperti harga yang terjangkau, pemesanan melalui internet dan telepon, serta waktu penanganan yang singkat. Di sisi maskapai, sistem low-cost menawarkan beberapa keuntungan seperti biaya tenaga kerja yang lebih 
rendah, perencanaan staf yang lebih fleksibel, serta biaya perawatan, suku cadang, dan pelatihan karyawan yang lebih murah (Vidovic, Steiner, \& Škurla Babic, 2006)

Akan tetapi, dari berbagai kemudahan yang ditawarkan, tentu tidak luput dari berbagai masalah yang akan timbul seiring dengan pesatnya perkembangan maskapai-maskapai berbiaya rendah di Indonesia. Masalah yang sering muncul seringkali berada pada aspek keamanan dan pelayanan. (Wahyuni \& Fernando, 2016). Masih banyak keluhan-keluhan yang diutarakan oleh pelanggan terhadap pelayanan yang diberikan oleh maskapai-maskpai berbiaya rendah di Indonesia. Untuk mendapatkan gambaran yang lebih luas mengenai bagaimana ulasan pelanggan mengenai pelayanan yang diberikan oleh maskapai berbiaya rendah di Indonesia, peneliti melakukan kajian ulasan-ulasan dari penumpang yang telah menggunakan jasa maskapai-maskapai tersebut. Peneliti melakukan kajian dari ulasan-ulasan penumpang yang pernah menggunakan jasa maskapai berbiaya rendah di Indonesia melalui laman TripAdvisor. TripAdvisor adalah sebuah perusahaan yang bergerak dibidang perjalanan, seperti pembelian tiket, perbandingan harga, ulasan-ulasan hotel, maskapai, restoran, pelayaran, serta membantu calon pelancong membuat keputusan yang terbaik untuk agenda berpergian mereka (TripAdvisor, 2018). Melalui laman TripAdvisor, pelancong juga dapat memberikan rating pada setiap aspek yang ditawarkan oleh penyedia jasa, sehingga calon-calon pelancong lainnya dapat mempertimbangan mengenai bagaimana pelayanan dan fasilitas yang ingin mereka terima dari perusahaan penyedia jasa tersebut.

Untuk melihat apakah terdapat keluhan dari berbagai ulasan para pengguna jasa maskapai-maskapai berbiaya rendah di Indonesia, peneliti berfokus untuk melihat ulasan-ulasan yang memiliki rating 1 dan 2, dimana artinya rating tersebut bernilai sangat buruk dan buruk. Maskapai Lion Air mendapatkan 662 ulasan yang bernilai sangat buruk dan buruk, dari total 1.827 ulasan. Ulasan yang diberikan pelanggan meliputi berbagai hal seperti jadwal, teknis, hingga masalah pelayanan yang diterima. Berfokus kepada awak kabin, terdapat banyak ulasan mengenai buruknya pelayanan yang diterima oleh pelanggan dari awak kabin. Banyak penumpang yang mengeluhkan perilaku awak kabin dalam melayani mereka seperti tidak menunjukkan senyum, melayani dengan ketus, serta tidak ramah dalam menjawab permintaan penumpang. Bahkan, terdapat ulasan awak kabin yang tidak membantu penumpang yang mengalami kesulitan dalam menaikan barang bawaan mereka kedalam bagasi kabin.

Maskapai selanjutnya adalah Air Asia Indonesia. Maskapai berbiaya rendah ini mendapatkan 320 ulasan yang bernilai buruk dan sangat buruk, dari total 2.261 ulasan. Ulasan yang diberikan pelanggan meliputi awak kabin yang tidak ramah terhadap penumpang, kabin, kursi-kursi, dan toilet yang tidak dibersihkan setelah semua penumpang turun dari pesawat, koordinasi antar awak kabin yang tidak baik sehingga keluhan penumpang tidak terselesaikan, hingga pada salah satu penerbangan, pelanggan mengeluh dikarenakan salah seorang awak kabin bermain gitar cukup lama dalam penerbangan. Dampaknya, banyak penumpang yang mengeluhkan bahwa mereka tidak dapat beristirahat, mengingat penerbangan tersebut merupakan penerbangan malam.

Kemudian, maskapai berikutnya adalah Citilink Indonesia. Maskapai ini mendapatkan 58 ulasan bernilai buruk dan sangat buruk, dari total 891 ulasan. Ulasan yang diberikan oleh penumpang meliputi awak kabin yang tidak ramah, terlihat ketus, cenderung jutek dalam melayani keluhan-keluhan penumpang. Seorang penumpang menceritakan bagaimana awak kabin menegurnya dengan tidak sopan dan cenderung membentak, ketika bayi penumpang tersebut sedang tertidur, karena awak kabin merasa bahwa mobilisasi mereka terganggu. Dalam penerbangan lainnya, seorang penumpang memberikan ulasan bahwa awak kabin memberikan pelayanan yang sangat buruk, serta tidak memberikan bantuan sama sekali terhadap penumpang disabilitas. Secara keseluruhan, penumpang-penumpang yang menulis ulasan di laman TripAdvisor mengenai pengalaman buruk yang mereka terima dalam hal 
pelayanan awak kabin juga menyatakan bahwa mereka tidak ingin menggunakan jasa seluruh maskapai tersebut, dikarenakan pelayanan yang mereka terima dari awak kabin berkualitas buruk.

Kepuasan pelanggan, yang menjadi tujuan utama dari pemberian pelayanan pada perusahaan yang bergerak di bidang jasa, menjadi sebuah hal yang penting. Tentunya, banyak faktor-faktor yang mempengaruhi bagaimana kualitas pelayanan yang diberikan. Salah satu yang cukup memiliki pengaruh signifikan adalah faktor kualitas pelayanan internal. Faktor ini menjadi penting dikarenakan untuk dapat memberikan pelayanan yang berkualitas tinggi kepada pelanggan, maskapai perlu untuk memahami bagaimana kualitas pelayanan ditingkatkan dari sisi pemangku kepentingan didalam perusahaan. Menurut Grönroos (1981) dan Heskett (1998), hal tersebut menjadi penting dikarenakan untuk mendapatkan pelanggan yang menunjukkan kepuasan, perusahaan harus memastikan bahwa karyawan mereka juga memiliki kepuasan terlebih dahulu (Frost \& Kumar, 2000). Menurut Parasuraman dkk., (1985), konsep kualitas pelayanan internal adalah evaluasi kualitas yang didasarkan pada proses pemberian layanan. Hasil dari layanan tersebut nantinya dapat digunakan untuk melihat poin-poin penting yang dapat digunakan untuk meningkatkan kinerja keamanan dan pelayanan, yang nantinya akan mengarah kepada kinerja perusahaan yang lebih baik. selain itu, menurut penelitian yang dilakukan oleh Kang dkk., (2000), menyatakan bahwa dengan melakukan asesmen terhadap kualitas layanan secara internal, serta memahami bagaimana berbagai dimensi mampu memberikan dampak terhadap kualitas pelayanan secara keseluruhan, dapat membuat organisasi atau perusahaan lebih efektif dalam merancang proses pemberian layanan secara lebih efektif. (Wahyuni \& Fernando, 2016).

Pelayanan dalam pesawat udara tidak akan pernah terlepas dari peran awak kabin. Setiap maskapai komersial, akan memiliki awak kabin. Anggota awak kabin ialah anggota kru yang telah memiliki kualifikasi yang baik, selain kru penerbangan dan anggota kru teknik, yang ditugaskan oleh operator untuk menjalankan tugas yang berhubungan dengan keamanan penumpang dan saat penerbangan sedang berlangsung (European Commision, 2012).

Awak kabin yang bertugas dalam maskapai berbiaya rendah atau biasa disebut Low-Cost Carrier seringkali mengalami fatigue (Bennett, 2003). Menurut penelitian yang dilakukan oleh Åkerstedt (2005), secara umum, fatigue dapat diartikan sebagai refleksi dari rasa kantuk sebagai hasil dari kurangnya tidur, desinkronisasi ritme sirkadian, dan keadaan terjaga yang lebih lama (Nesthus, 2007). Fatigue pada awak kabin dapat memberikan dampak fisiologis. Beberapa ciri-ciri seseorang mengalami fatigue adalah komunikasi yang buruk, menurunnya daya ingat, lesu, serta menurunnya respon (Darby \& Walls, 1998).

Berdasarkan pemaparan masalah-masalah diatas, maka peneliti tertarik untuk mengetahui apakah terdapat hubungan antara persepsi dampak work fatigue dengan persepsi kualitas pelayanan internal awak kabin maskapai berbiaya rendah di Indonesia.

\section{METODE}

\section{Partisipan}

Penelitian ini melibatkan awak kabin dari beberapa maskapai yang berbiaya rendah di Indonesia. Jumlah partisipan dalam penelitian ini berjumlah 40 orang.

\section{Prosedur}

Proses pengumpulan data yang akan digunakan pada penelitian ini adalah dengan menggunakan skala. Pengambilan data dilakukan dari bulan Oktober 2018 hingga Januari 2019. Pengambilan data dilakukan dengan menyebarkan kuesioner penelitian yang telah dibuat dalam bentuk digital menggunakan Google 
Form. Kuesioner penelitian berbentuk digital ini disebarkan melalui media sosial seperti Instagram, Twitter, LinkedIN, LINE, dan Whatsapp yang dimiliki oleh peneliti. Selain itu, peneliti juga mencetak kuesioner pennelitian tersebut untuk dapat disebarkan kepada awak kabin ketika peneliti sedang berpergian menggunakan maskapai tersebut.

\section{Pengukuran}

Skala pengukuran ini digunakan oleh peneliti guna mengkuantifikasi informasi yang diterima dari responden. Skala yang digunakan pada penelitian ini terdiri dari beberapa pernyataan yang diberikan kepada responden. Dalam penelitian ini, peneliti menggunakan 2 skala untuk mengukur 2 hal yang berbeda, yaitu skala untuk mengukur pelayanan penerbangan untuk mengukur variabel kualitas pelayanan, dan Fatigue Impact Scale (FIS) untuk mengukur variabel work fatigue. Fatigue Impact Scale (FIS) dikembangkan oleh Fisk dkk. (1994). Skala ini terdiri dari 40 item dengan menggunakan skala 0 (bukan masalah) hingga 4 (masalah sangat besar).

Skala Pelayanan Penerbangan disusun oleh Nameghi dan Ariffin (2013). Skala yang terdiri dari 19 item ini digunakan untuk mengukur kualitas pelayanan dalam penerbangan. Dimensi-dimensi pada skala ini merupakan pengembangan dari dimensi yang ada pada teori kualitas pelayanan yang dikemukakan oleh Parasuraman. Pada penelitian ini, peneliti menghilangkan dua item dikarenakan item tersebut tidak relevan untuk digunakan pada lingkup penelitian ini. Pada penelitian ini, peneliti telah melakukan uji coba alat ukur. Hal ini dilakukan dikarenakan alat ukur pada penelitian ini belum pernah digunakan di Indonesia, sehingga uji coba perlu dilakukan untuk melihat apakah alat ukur Fatigue Impact Scale (FIS) dan Pelayanan Penerbangan mampu menjadi alat ukur yang dapat dikatakan reliabel untuk dapat digunakan di Indonesia. Uji coba yang dilakukan adalah uji coba terpakai dengan melibatkan 30 subjek

Analisis data

Berdasarkan hasil uji coba reliabilitas alat ukur Fatigue Impact Scale (FIS) ini sangat reliabel untuk digunakan di Indonesia $(r=0,972)$. Sedangkan untuk reliabilitas alat ukur Pelayanan Penerbangan menunjukkan bahwa alat ukur Pelayanan Penerbangan cukup reliabel untuk digunakan di Indonesia $(r=0,799)$. Analisis hipotesis yang digunakan dalam penelitian ini yaitu análisis uji korelasi.

HASIL PENELITIAN

Tabel 1. Hasil Uji Analisis Statistik Deskriptif Rata-rata Kedua Variabel

\begin{tabular}{cccccccc}
\hline Variabel & N & Maksimum & Minimum & Mean & SD & Skewness & Kurtosis \\
\hline Work Fatigue & 40 & 3,73 & 0,27 & 1,80 & 0,944 & 0,355 & $-0,849$ \\
\hline $\begin{array}{c}\text { Kualitas } \\
\text { Pelayanan }\end{array}$ & 40 & 6,00 & 4,31 & 5,24 & 0,528 & 0,136 & $-1,266$ \\
\hline
\end{tabular}

Berdasarkan tabel diatas, dapat dilihat bahwa nilai minimum pada variabel work fatigue adalah 0,27 dan nilai tertinggi 3,73. Sedangkan di variabel kualitas pelayanan, nilai mínimum berada pada angka 4,31 serta nilai tertinggi berada pada angka 6,00. Nilai mean yang ditunjukkan pada tabel diatas berada pada angka 1,80 untuk variabel work fatigue, serta angka 5,24 untuk variabel kualitas pelayanan. Melalui nilai mean diatas kita mampu mengetahui bagaimana respon subjek terhadap kedua variabel. Pada variabel work fatigue, nilai mean menunjukkan angka 1,80 atau dapat dibulatkan menjadi 2 pada skala 0-4. Artinya subjek penelitian ini mempersepsikan kelelahan yang mereka alami sebagai masalah

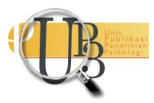


sedang. Hal ini dapat dilihat dari angka 1,80 yang dimana mendekati skor 2 (masalah sedang) pada alat ukur variabel work fatigue. Pada variabel kualitas pelayanan, nilai mean menunjukkan angka 5,24 atau dapat dibulatkan menjadi 5 yang berarti subjek penelitian ini mempersepsikan kualitas pelayanan mereka sebagai baik dikarenakan nilai mean variabel ini berada diantara skor 5 (setuju) dan 6 (sangat setuju).

Data yang diperoleh melalui survei kemudian dianalisis. Langkah pertama yaitu análisis uji asumsi. Berdasarkan data yang diperoleh dari uji normalitas work fatigue $(p=0.041)$ yang berarti bahwa persebaran data tidak normal karena $(p<0.05)$. Sedangkan pada variable kualitas pelayanan $(p=0.56)$ menandakan bahwa persebaran data pada variable kualitas pelayanan dikatakan normal.

Berdasarkan uji linearitas yang telah dilakukan dapat disimpulkan bahwa data penelitian ini tidak linear $(p=0.265)$. Mengacu kembali pada asumsi dasar pengambilan keputusan pada uji linearitas yaitu data akan dikatakan linear apabila $(\mathrm{p}<0.05)$. Sebaliknya, apabila $(p>0.05)$, maka data tersebut dapat dikatakan tidak linear.

Melalui hasil uji asumsi yang telah dilakukan, dimana uji asumsi yang dilakukan adalah uji normalitas dan uji linearitas, dapat disimpulkan bahwa data pada penelitian ini memiliki distribusi tidak normal pada variabel work fatigue, distribusi normal pada variabel kualitas pelayanan dan data tidak linear.

Pada analisis korelasi yang telah dilakukan, dapat dketahui bahwa korelasi antara variable workfatigue dan kualitas pelayanan tergolong lemah dan tidak signifikan $(r(40)=0.09, p=0.582)$ Artinya, variabel pada penelitian ini tidak menunjukkan adanya hubungan antar variabel. Hal tersebut juga berarti bahwa Ho tidak dapat ditolak sehingga dengan kata lain, tidak terdapat hubungan antara persepsi dampak work fatigue dengan persepsi kualitas pelayanan internal pada awak kabin maskapai berbiaya rendah di Indonesia.

\section{DISKUSI}

Berdasarkan uji korelasi yang telah dilakukan, telah didapatkan skor nilai $(p=0.295)$ atau lebih besar dari 0.05. Jika dilihat kembali pada acuan menilai korelasi berdasarkan taraf signifikansi, maka dapat dikatakan bahwa pada penelitian ini hipotesis ditolak, yang artinya tidak terdapat hubungan antara persepsi dampak work fatigue dengan persepsi kualitas pelayanan awak kabin maskapai berbiaya rendah di Indonesia. Sebelum dilakukannya uji korelasi, peneliti terlebih dahulu telah melakukan uji asumsi berupa uji normalitas dan uji linearitas. Uji normalitas yang digunakan dalam penelitian ini adalah melalui skewness dan kurtosis. Berdasarkan pada tabel 1, nilai skewness pada variabel work fatigue menunjukkan angka 0.344. Sedangkan pada variabel kualitas pelayanan, nilai skewness menunjukkan nilai 0.051. Pada nilai kurtosis, variabel work fatigue menunjukkan nilai -0.894 . Sedangkan pada variabel kualitas pelayanan nilai kurtosis yang ditunjukkan adalah -1.167. Hasil yang didapat dari penelitian ini menunjukkan tidak adanya hubungan antara work fatigue dengan kualitas pelayanan.

Tidak terdapatnya hubungan antara work fatigue dengan kualitas pelayanan awak kabin maskapai berbiaya rendah di Indonesia dalam penelitian ini dapat disebabkan oleh beberapa hal. Salah satu diantaranya adalah adanya social desirability effect. Social desirability effect adalah kecenderungan seseorang untuk tidak benar-benar melaporkan keadaan yang mereka alami sebenarnya dalam melakukan self-report. Social desirability effect juga dapat terjadi dikarenakan subjek cenderung untuk memilih perilaku yang lebih diterima secara sosial dan bahkan melakukan over report terhadap hal tersebut (Latkin, 2017). Paulhus (1984) menjelaskan bahwa terdapat dua komponen dalam social desirability effect. Komponen pertama adalah impression management. Komponen ini menjeleaskan 
bagaimana seseorang mengatur presentasi dirinya agar sesuai dengan situasi atau sesuai dengan ekspektasi suatu kelompok. Komponen kedua adalah self-deception, dimana komponen ini dapat terjadi tanpa disadari, dan didasari pada motivasi untuk tetap mempertahankan konsep diri yang positif (Latkin, 2017). Rata-rata skor subjek pada penelitian ini menunjukan skor tinggi pada rata-rata varaiabel kualitas pelayanan. Artinya, subjek cenderung untuk mempersepsikan kualitas pelayanan yang mereka berikan memiliki kualitas yang baik. hal tersebut dapat disebabkan oleh ketidaksadaran subjek dalam menjawab pernyataan kuesioner karena didasari oleh motivasi untuk mempertahankan konsep diri mereka agar tetap positif. Social Desirability Effect banyak ditemui pada skala-skala selfreport. Walau skala self-report memiliki tingkat validitas dan reliabilitas yang tinggi, namun mereka memiliki keterbatasan yang salah satunya adalah rentan mengalami social desirability effect (Perugini \& Banse , 2007).

Selanjutnya, tidak adanya hubungan work fatigue dengan kualitas pelayanan awak kabin maskapai berbiaya rendah di Indonesia dapat disebabkan oleh awak kabin yang mempersepsikan bahwa kualitas pelayanan mereka berada pada kategori baik, dengan mepersepsikan bahwa work fatigue sebagai masalah yang sedang. Dengan kata lain, awak kabin tetap mampu memberikan kualitas pelayanan yang baik, walaupun dengan adanya work fatigue. Subjek mempersepsikan work fatigue yang mereka alami masih belum berada pada tingkatan yang cukup untuk dapat memberikan dampak langsung terhadap kualitas pelayanan yang mereka berikan. Hal ini didukung oleh penelitian yang dilakukan oleh Majore, Kalalo, dan Bidjuni (2018) berjudul "Hubungan Kelelahan Kerja dengan Kinerja Perawat di Instalasi Rawat Inap RSU Pancaran Kasih GMIM Manado". Penelitian tersebut menjelaskan bahwa mayoritas responden penelitian tidak mengalami kelelahan kerja dan memiliki kinerja baik sebanyak 77,3\%. Sedangkan pada subjek yang mengalami kelelahan kerja dan memiliki kinerja yang buruk sebanyak 6,8\%, serta subjek dengan kelelahan kerja dengan memiliki kinerja yang baik sebesar 13,6\%. Subjek yang memiliki kinerja baik dapat menjamin konsumen puas dengan pelayanan keperawatan yang diberikan (Majore, Kalalo, \& Bidjuni, 2018). Penelitian tersebut menyebutkan bahwa 13,6\% subjek yang mengalami kelelahan kerja tidak mengalami penurunan pada kinerja mereka. Sebuah penelitian yang dilakukan di Pakistan yang berjudul "The Impact of Trust, and Cabin Crew Performance on Customer Satisfaction" menemukan bahwa kinerja awak kabin berdampak terhadap kepuasan pelanggan. Mayoritas dari responden menyatakan bahwa mereka puas dengan kinerja yang ditunjukkan oleh awak kabin melalui pelayanannya (Safwan, 2012). Sehingga, perlu diidentifikasi pada penelitian selanjutnya apakah kinerja dapat menjadi variabel mediator apabila ingin mengetahui hubungan antara kelelahan kerja dengan kualitas pelayanan, terutama dalam konteks awak kabin yang bekerja di maskapai berbiaya rendah di Indonesia.

Berdasarkan hasil penelitian ini pula, dapat dilihat bahwa awak kabin mempersepsikan kualitas pelayanan yang mereka berikan berada dalam kategori baik. Akan tetapi, masih banyak dijumpai keluhan-keluhan pelanggan yang menggunakan maskapai berbiaya rendah tersebut dimana keluhankeluhan tersebut mengarah kepada kualitas pelayanan yang diberikan oleh awak kabin maskapai berbiaya rendah di Indonesia. Hal tersebut dapat disebabkan oleh adanya perbedaan persepsi mengenai kualitas pelayanan yang dimiliki oleh awak kabin dan kualitas pelayanan yang dimiliki oleh pelanggan. Hal ini didukung oleh temuan dari penelitian yang dilakukan oleh Dinesh \& Pushpakaran (2016) mengenai perbedaan persepsi dalam kualitas pelayanan. Hasil dari penelitian tersebut menemukan bahwa terdapat perbedaan yang signifikan antara persepsi kualitas layanan dari karyawan sebagai penyedia layanan dan pelanggan sebagai penerima layanan. Karyawan cenderung untuk mempersepsikan kualitas layanan yang mereka berikan sebagai kualitas layanan yang berkualitas tinggi, sedangkan pada pelanggan terjadi perbedaan persepsi dimana pelanggan mempersepsikan kualitas layanan yang mereka terima bernilai rendah jika dibandingkan dengan kualitas pelayanan dari 
persepsi karyawan (Dinesh \& Pushpakaran, 2016).

\section{SIMPULAN}

Berdasarkan penelitian yang telah dilakukan, telah didapatkan hasil yang menunjukkan bahwa tidak terdapat hubungan antara persepsi dampak work fatigue dengan persepsi kualitas pelayanan internal awak kabin maskapai berbiaya rendah di Indonesia. Penelitian ini juga menemukan bahwa work fatigue merupakan masalah yang dipersepsikan oleh awak kabin sebagai masalah yang sedang, sehingga dapat menyebabkan tidak terdampaknya kualitas pelayanan mereka yang dimana menurut hasil penelitian ini pula, mereka mempersepsikan kualitas pelayanan mereka memiliki kualitas yang baik.

\section{UCAPAN TERIMA KASIH}

Penulis mengucapkan terima kasih pada seluruh responden yang terlibat dalam penelitian ini sehingga penelitian ini dapat terselesaikan dengan baik. Penulis juga mengucapkan terima kasih kepada keluarga, dosen, teman, serta semua pihak yang terlibat dalam penelitian ini.

\section{DEKLARASI POTENSI TERJADINYA KONFLIK KEPENTINGAN}

Fikri Ahmad Maulana dan Cholichul Hadi tidak bekerja, menjadi konsultan, memiliki saham, atau menerima dana dari perusahaan atau organisasi mana pun yang akan mengambil untung dari naskah ini, dan telah mengungkapkan bahwa ia tidak memiliki afiliasi selain yang telah disebut di atas.

\section{PUSTAKA ACUAN}

Bennett, S. A. (2003). Flight crew stress and fatigue in low cost commercial air operation - an appraisal. International Journal of Risk Assessment Vol 4, 207-232.

Darby, F., \& Walls, C. (1998). Stress and Fatigue; Their impact on health and safety in the workplace. Auckland: Occupational Safety and Health Service of the Department of Labour.

Dinesh, T., \& Pushpakaran, K. (2016). Perceptual Differences in Service Quality. IOSR Journal of Business and Management Volume 18, 73-80.

European Commision. (2012). Commision Regulation (EU) no. 290/2012. Official Journal of the European Union, 1-56.

Frost, F. A., \& Kumar, M. (2000). INTSERVQUAL - an internal adaptation of the GAP model in a large service organisation. Journal of Services Marketing, 358-377.

Latkin, C. A.-R. (2017). The relationship between social desirability bias and self-reports of health, substance use, and social network factors among urban substance users in Baltimore, Maryland. Addictive behaviors, 73, 133-136.

Majore, C. E., Kalalo, F. P., \& Bidjuni, H. (2018). Hubungan Kelelahan Kerja dengan Kinerja Perawat di Instalasi Rawat Inap RSU Pancaran Kasih GMIM Manado. e-Journal Keperawatan Volume 6 Nomor 1, 1-7.

Nesthus, T. S.-B. (2007). Flight Attendant Fatigue. Washington, DC: Office of Aerospace Medicine, Federal Aviation Administration.

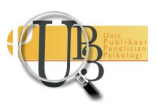


Paulhus, D. L. (1984). Two-component models of socially desirable responding. Journal of personality and social psychology, 46(3), 598.

Perugini, M., \& Banse , R. (2007). Personality, Implicit Self-concept and Automaticity. European Journal of Personality, 1-8.

Safwan, N. H. (2012). The impact of trust and cabin crew performance on customers' satisfaction. OIDA International Journal of Sustainable Development, 4(5).

TripAdvisor. (2018, April 16). About TripAdvisor. Retrieved from TripAdvisor: https://tripadvisor.mediaroom.com/us-about-us

Vidovic, A., Steiner, S., \& Škurla Babic, R. (2006). Impact of Low-Cost Airlines on the European Air Transport Market. 10th International Conference on Traffic Science ICTS 2006: Globalization and Transportation. .

Wahyuni, I. S., \& Fernando, Y. (2016). Growing pains the low cost carrier sector in Indonesia: Internal service quality using a critical incident technique. Safety Science, 214-223. 